\title{
Effect of Some Factors on Number of Services per Conception in Dairy Cows
}

\section{Kamil Siatka1 ${ }^{1}$ Anna Sawa1, Sylwia Krężel-Czopek ${ }^{1 *}$, Dariusz Piwczyński² and Mariusz Bogucki ${ }^{1}$}

${ }^{1}$ Department of Cattle Breeding, UTP University of Science and Technology in Bydgoszcz, Mazowiecka 28, 85-084 Bydgoszcz, Poland ${ }^{2}$ Department of Genetics and General Animal Breeding, Faculty of Animal Science and Biology, UTP University of Science and Technology in Bydgoszcz, Mazowiecka 28, 85-084 Bydgoszcz, Poland

\begin{abstract}
The study involved 55685 Polish Holstein-Friesian cows whose services per conception (SPC) averaged 2.2. Statistical analysis performed using the GLM procedure of SAS, showed significant differences in SPC value within different factors. The greatest changes were associated with daily milk yield of the cows; as it increased from $\leq 20$ $\mathrm{kg}$ to $>40 \mathrm{~kg}$, the number of services required to conceive increased by 0.6 . SPC value deteriorated also with an increasing number of cows in the herd (by 0.37 ) and with an increase in milk somatic cell count, being indicative of mastitis (by 0.11). The opposite situation existed for an increase in herd production level and lengthening of the interval between calving and first insemination (decrease of SPC by 0.31 ). It was also found that summer was the least favourable period for insemination and winter the most favourable ( $S P C=2.28$ vs 2.16$)$. Analysis of the results demonstrates that it is necessary and appropriate to account for these factors when aiming to improve cow fertility.
\end{abstract}

Keywords: Dairy cows; Services per conception; Cattle; Fertility

\section{Introduction}

Alongside parameters of milk performance, reproductive parameters are very important in terms of management and production profitability [1]. Number of services per conception (SPC) is frequently used as an indicator of fertility and the optimum value is considered to range between 1.6 and 1.8 [2]. Today, first service conception rate ranges from 40 to $44 \%$ [3], which makes SPC higher than optimal. According to Mordak [4], the number of services per conception around 2 is still acceptable, but values exceeding 3 are indicative of considerable organizational and/or health problems with reproduction.

The results of performance recording and research findings [2,5-7] show that fertility of (especially high-producing) cows is deteriorating. High-yielding cows show a higher ability to mobilize energy reserves during the early lactation period [8,9]. This may result in metabolic changes, leading to a decrease in reproductive parameters due to functional changes of the reproductive system [10], which translate into lower conception rate and increased likelihood of pregnancy loss [11].

The aim of the study was to analyse the effect of selected factors on number of services per conception in dairy cows.

\section{Materials and Methods}

The study involved 55685 Polish Holstein-Friesian cows recorded in the Pomerania and Kujavia regions, under evaluation of dairy performance milk, performance assessment conducted by Polish Federation of Cattle Breeders and Dairy Farmers. The cows had calved first in 2005-2012 and were used until 2014, in 1835 herds. For which the following data were acquired from the SYMLEK database: date of first and second calving; number of inseminations in the first and second production cycle; milk traits from test-day yields obtained up to the 30th day before first insemination, during the period preceding the 180th day of first and second lactation [kg milk, urea level (mg.l $\left.{ }^{-1}\right)$, somatic cell count (SCC)].
The GLM procedure of SAS [12] was used in the statistical calculations and significant differences were analysed with the Scheffé test. The effect of the following factors was examined: herd production level ( $\leq 7000,7001-9000,>9000 \mathrm{~kg}$ milk); season of first insemination (spring: March-May, summer: July-August, autumn: SeptemberNovember, winter: December-February); number of cows in herd $(\leq 20$, 21-50, 51-200, >200 cows); age of cows (first lactation, second lactation); lactation period during first insemination $(\leq 60,61-90,91-120,121-$ $150,151-180$ days); daily yield ( $\leq 20,20.1-30,30.1-40$ and $>40 \mathrm{~kg}$ milk); milk urea level $\left(\leq 150,150-300,>300 \mathrm{mg}^{-1} \mathrm{l}^{-1}\right)$; under healthiness on the SCC base in $1 \mathrm{ml}$ of milk ( $\leq 200000,200001-400000,400001-1000000$, $>1000000$ ).

The following linear model were used:

$\mathrm{Y}_{\mathrm{ijklmnopr}}=\mu+\mathrm{a}_{\mathrm{i}}+\mathrm{b}_{\mathrm{j}}+\mathrm{c}_{\mathrm{k}}+\mathrm{d}_{1}+\mathrm{f}_{\mathrm{m}}+\mathrm{g}_{\mathrm{n}}+\mathrm{h}_{\mathrm{o}}+\mathrm{i}_{\mathrm{p}}+\mathrm{e}_{\mathrm{ij} \mathrm{jlm} \text { mopr }}$

where: $\mu$ - overall mean, $\mathrm{a}_{\mathrm{i}}$ - is the effect of $i$-th age of cows (first lactation, second lactation), $\mathrm{b}_{\mathrm{j}}$ - is the effect of $j$-th herd production level ( $\leq 7000,7001-9000$ and $>9000 \mathrm{~kg}$ milk), $c_{k}$ - is the effect of $k$-th season of first insemination (spring: March-May, summer: July-August, autumn: September-November, winter: December-February), $\mathrm{d}_{1}$ - is the effect of $l$-th lactation period during first insemination $(\leq 60,61-90,91-120,121$ $150,151-180$ days), $\mathrm{f}_{\mathrm{m}}$ - is the effect of $m$-th number of cows in herd ( $\leq$ 20, 21-50, 51-200 and $>200$ cows), $g_{n}$ - is the effect of $n$-th milk urea level $\left(\leq 150,150-300\right.$ and $\left.>300 \mathrm{mg} \cdot 1^{-1}\right), \mathrm{h}_{\mathrm{o}}$ - is the effect of $o$-th LKS base in 1

*Corresponding author: Sylwia Krężel-Czopek, Department of Cattle Breeding, UTP University of Science and Technology in Bydgoszcz, Mazowiecka 28, 85084 Bydgoszcz, Poland, Tel: +48523749710; E-mail: krezel@utp.edu.pl

Received August 03, 2017; Accepted August 16, 2017; Published August 17, 2017

Citation: Siatka K, Sawa A, Czopek SK, Piwczyński D, Bogucki M (2017) Effect of Some Factors on Number of Services per Conception in Dairy Cows. J Vet Sci Technol 8: 465. doi: 10.4172/2157-7579.1000465

Copyright: @ 2017 Siatka K, et al. This is an open-access article distributed under the terms of the Creative Commons Attribution License, which permits unrestricted use, distribution, and reproduction in any medium, provided the original author and source are credited. 
$\mathrm{ml}$ of milk ( $\leq 200000,200001-400000,400001-1000000,>1000000), \mathrm{i}_{\mathrm{p}}-$ is the effect of $p$-th daily yield ( $\leq 20,20,1-30,30,1-40$ and $>40 \mathrm{~kg}$ milk), $\mathrm{e}_{\mathrm{ijk} k \mathrm{knnopr}}$ - is the random error of observations. Significant differences were analysed using Scheffé test.

\section{Results}

The cows exhibited low fertility with SPC of 2.20 (Table 1 ). Compared to secundiparous cows, primiparous cows required 0.06 more dose of semen to conceive.

Herd production level is the outcome of many (mainly environmental) factors and serves as a measure of the quality of rearing conditions. As the herd production level increased, SPC decreased from 2.36 to 2.05 . This shows that reproductive problems were most efficiently solved in herds producing $>9000 \mathrm{~kg}$ of milk. It may be that these herds achieved better cow fertility because they practised stricter zootechnical and veterinary controls, and cooperated more closely with the inseminators.

The best period for insemination of cows is autumn and winter, the seasons with lower daily temperatures in Poland. The number of semen doses needed for the conception was 2.16-2.20 from autumn to spring, but increased significantly in summer (2.28).

SPC took increasingly favourable values with the increasing interval between calving and first insemination. Cows inseminated before 60 days of lactation, compared to their contemporaries inseminated later, had the significantly highest SPC (2.41). With increasing interval between first insemination and the preceding calving, the number of services required for conception decreased to 2.10 .

Lower number of cows in herd ( $<20$ and $20-50$ cows $)$ had a positive effect on the number of semen doses required to conceive, with significant differences between very small ( $\leq 20$ cows) and small herds (21-50 cows) and large (50-200 cows) and very large herds (>200 cows).

Among the investigated factors, daily milk production level differentiated SPC values the most. As daily milk yield of the cows increased from $\leq 20 \mathrm{~kg}$ to $>40 \mathrm{~kg}$, SPC values increased by as much as 0.6 .

Analysis of the results in Table 1 shows that the urea level in milk from test-day yields preceding the insemination, did not cause significant differences in SPC value, assuming the highest (least favourable) value of 2.24 for cows producing milk with urea content in excess of $300 \mathrm{mg} \cdot \mathrm{l}^{-1}$.

The milk somatic cell count, which is often considered as an indicator of udder health [13], proved to be significantly correlated to the number of services per conception. The increase in milk somatic cell count, being indicative of the advanced stage of mastitis, caused the number of services per conception to increase from 2.15 to 2.26 .

\begin{tabular}{|c|c|c|c|c|c|}
\hline \multicolumn{2}{|c|}{ Factor and range } & \multirow{3}{*}{$\begin{array}{c}\mathbf{N} \\
55685 \\
33060\end{array}$} & \multirow{3}{*}{\begin{tabular}{|c|} 
SPC \\
$2.24^{\mathrm{A}}$ \\
$2.18^{\mathrm{A}}$
\end{tabular}} & \multirow{3}{*}{$\begin{array}{c}\mathbf{F} \\
12.74\end{array}$} & \multirow{3}{*}{$\begin{array}{l}\text { P-value } \\
0.0004\end{array}$} \\
\hline \multirow{2}{*}{ Number of lactation } & 1 & & & & \\
\hline & 2 & & & & \\
\hline \multirow{3}{*}{ Herd production level $(\mathrm{kg})$} & $<7000$ & 34869 & $2.36^{A B}$ & \multirow{3}{*}{19.93} & \multirow{3}{*}{$<0.0001$} \\
\hline & $7000-9000$ & 36708 & $2.21^{A C}$ & & \\
\hline & $>9000$ & 17168 & $2.05^{\mathrm{BC}}$ & & \\
\hline \multirow{4}{*}{ Season of first insemination } & winter: December-February & 20384 & $2.16^{\mathrm{A}}$ & \multirow{4}{*}{9.34} & \multirow{4}{*}{$<0.0001$} \\
\hline & spring: March-May & 24811 & $2.20^{\mathrm{B}}$ & & \\
\hline & summer: July-August & 21339 & $2.28^{\mathrm{ABC}}$ & & \\
\hline & autumn: September-November & 22211 & $2.19^{\mathrm{c}}$ & & \\
\hline \multirow{5}{*}{ Lactation period during first insemination (days) } & $\leq 60$ & 35022 & $2.41^{\mathrm{ABCD}}$ & \multirow{5}{*}{39.92} & \multirow{5}{*}{$<0.0001$} \\
\hline & $61-90$ & 27047 & $2.23^{\mathrm{Aa}}$ & & \\
\hline & $91-120$ & 15199 & $2.20^{\mathrm{B}}$ & & \\
\hline & $121-150$ & 7638 & $2.11^{\mathrm{Ca}}$ & & \\
\hline & $151-180$ & 3839 & $2.10^{\mathrm{D}}$ & & \\
\hline \multirow{4}{*}{ Herd size (cows) } & $<20$ & 14976 & $2.04^{\mathrm{AB}}$ & \multirow{4}{*}{63.32} & \multirow{4}{*}{$<0.0001$} \\
\hline & $21-50$ & 32270 & $2.06^{\mathrm{CD}}$ & & \\
\hline & $51-200$ & 20691 & $2.32^{\mathrm{ACa}}$ & & \\
\hline & $>200$ & 20808 & $2.41^{\mathrm{BDa}}$ & & \\
\hline \multirow{4}{*}{ Daily milk yield (kg) } & $\leq 20.0$ & 14725 & $1.95^{\mathrm{ABa}}$ & \multirow{4}{*}{37.17} & \multirow{4}{*}{$<0.0001$} \\
\hline & $20.1-30.0$ & 40219 & $2.09^{\mathrm{CDa}}$ & & \\
\hline & $30.1-40.0$ & 25064 & $2.25^{A C E}$ & & \\
\hline & $>40.0$ & 8737 & $2.54^{\mathrm{BDE}}$ & & \\
\hline \multirow{3}{*}{ Milk urea level $\left(\mathrm{mg} . \mathrm{I}^{-1}\right)$} & $\leq 150$ & 25611 & 2.20 & \multirow{3}{*}{2.63} & \multirow{3}{*}{0.0721} \\
\hline & $150-300$ & 48542 & 2.19 & & \\
\hline & $>300$ & 14592 & 2.24 & & \\
\hline \multirow{4}{*}{ Somatic cell count per ml of milk } & $\leq 200000$ & 58948 & $2.15^{\mathrm{AB}}$ & \multirow{4}{*}{9.82} & \multirow{4}{*}{$<0.0001$} \\
\hline & $200001-400000$ & 11236 & 2.19 & & \\
\hline & $400001-1000000$ & 9473 & $2.24^{\mathrm{A}}$ & & \\
\hline & $>1000000$ & 9088 & $2.26^{\mathrm{B}}$ & & \\
\hline
\end{tabular}

Values differing significantly within a factor are marked with the same letters as ${ }^{A, B}$ at $P \leq 0.01, a, b$ at $P \leq 0.05$

Table 1: Effect of some factors on number of services per conception (SPC). 


\section{Discussion}

Other studies concerning the effect of cow's age on fertility show varying results. Lithuanian research [14] shows that primiparous cows require the highest number of inseminations (SPC of 1.67) and third lactation cows the lowest (SPC of 1.42) to conceive. Similarly, for highly productive Montbeliard cows, Januś and Borkowska [6] achieved better results in secundiparous (SPC of 1.81) compared to primiparous cows (1.98). Lavon et al. [15] observed that primiparous cows conceive more easily than multiparous cows. Muller et al. [16] found the number of services per conception to increase linearly with an increasing number of lactations. In turn, Vacek et al. [17], Ahmadzadeh et al. [18] and Piccardi et al. [1] demonstrated that the number of calvings has no significant effect on reproductive efficiency measured by SPC.

In our study, the season of the first insemination after calving caused significant differences in SPC, with the summer being the least favourable period. Also other authors [19-21] concluded that high ambient temperatures (heat stress) may adversely affect fertilization and embryo survival. Exposure to high temperatures may degenerate ovarian theca and granulosa cells, reduce steroidogenesis, and also compromise ovarian progesterone production [19]. High ambient temperatures contribute to a decrease in feed intake [22], leading to a negative energy balance and the associated significant hormonal changes. Also the decreased intrauterine blood circulation may affect reproductive efficiency by increasing temperature inside the uterus $[8,20]$.

The effect of lactation period on the number of services per conception, observed in our study, may be attributed to the success at first insemination which increases with the increasing interval from calving [23]. Yusuf et al. [24] noted a positive effect of the increasing interval between insemination and calving on first insemination success. They obtained SPC of 1.9-2.4 semen doses, with the highest values found in the early lactation periods (up to 60 days), which corresponds with our findings. Also Swedish studies [25] indicate that early insemination of the cows after calving ( $<60$ days) results in a higher number of services per conception, recommending that the inseminations should be shifted in time to make them more effective.

The negative effect of the increased number of cows in a herd on SPC value may be due to the more difficult monitoring of individual animals in terms of feed intake or estrus detection as herd size increases [26]. In turn, El-Tarabany and El-Tarabany [20] show that housing a large number of animals under one in the cowshed may negatively affect the house climate. Especially during the period of high temperatures and with the poor quality of animal cooling systems, this may cause a deterioration in reproductive parameters.

The increasing number of services per conception (from 1.95 to 2.54 ), associated with an increase in daily milk yield of the cows from $\leq$ $20 \mathrm{~kg}$ to $>40 \mathrm{~kg}$ could be the result of excessive metabolic burden on the highest yielding cows. This is due to the high nutritional requirements that are difficult to meet. The nutrients supplied are in the first place used for maintenance and milk production [27,28], leading to competition between milk yield and fertility $[9,25]$, thus resulting in poorer SPC value.

Breeders use milk urea level not only as an important and objective indicator of a well-balanced cow diet in terms of protein and energy $[5,29]$, but also as a potential trait in the improvement of fertility and health [30].
Skrzypek et al. [30] reported that the effect of urea level on reproductive parameters is nonlinear, and showed that the most favourable urea level in terms of reproduction is between 201 and 250 mg..$^{-1}$ (SPC of 1.85), whereas values beyond $300 \mathrm{mg}$ per milk litre caused a significant decrease in conception rate (SPC of 2.52). Likewise, König et al. [29] showed a deterioration in fertility of the cows whose milk contained more than $300 \mathrm{mg}$ of urea $\left(\mathrm{mg} . \mathrm{l}^{-1}\right)$.

According to Sawa et al. [31] the correlations between milk urea level and service per conception were positive and statistically significant though very low $(0,02)$. Thus, the increase in milk urea concentration was due to increased dose of semen needed for conception (II). Herd milk production level, age of cows and lactation period were the factors that had the greatest effect on the relationship between milk urea levels and cow fertility parameters. The relationship between milk urea level and fertility was stronger in cows from herds with $>6000 \mathrm{~kg}$ milk yield, in first-calf heifers and in cows at 3 months of lactation.

Nourozi et al. [32] considered the milk urea level of 120-160 (mg. $\left.{ }^{-1}\right)$ as optimal for reproduction. In turn, the results of Czech studies [23] showed that milk urea level has no effect on reproductive parameters such as SPC, although the average values were similar to those obtained in our study (SPC of 2.12-2.36). This relationship could be attributed to the negative energy balance in high-yielding cows, and not to the urea level itself. Another explanation of this phenomenon could be the adaptability of the cows to high feed protein content, which translates into a reduction of the negative effect of high milk urea content on their fertility [7].

Increasing attention has recently been given to udder inflammation in the context of reproductive disorders [13]. Results show that mastitis diagnosed in the period preceding insemination has a negative effect on reproductive efficiency in Holstein-Friesian cows [15]. According to Ahmadzadeh et al. [18] and Pinedo et al. [33], udder inflammation is conducive to the presence of estrous cycle disturbances. Morris et al. [34] indicate that elevated SCC in milk is paralleled by delayed signs of estrus, which, in addition, are weaker. Pinedo et al. [33], who investigated the period before first insemination, found that the increase in SCC beyond 283 thous/ $\mathrm{ml}$ was accompanied by an increase in SPC (by 0.49). In a study with the Czech population of Holstein cows, Vacek et al. [17] reported a significantly negative effect of clinical mastitis on the number of services per conception, and also showed that cows affected by two cases of subclinical mastitis per lactation exhibited higher SPC values (2.58) compared to those with no or one incidence of subclinical mastitis (SPC of 1.94 and 2.34, respectively). Also Ahamadzadeh et al. [18] demonstrated significant differences between the least square means for SPC between cows with clinical mastitis and healthy animals (2.1 vs 1.6 inseminations). Likewise, Gunay and Gunay [35] recognized clinical mastitis as a factor reducing fertility, with SPC increasing to 2.1 and 3.4 in the affected groups compared to 1.8 in the control group. Also Lomander et al. [25] consider increasing SCC (from less than 200 thous. cells/ml to more than 200 thous. cells/ml during a month) as the cause of increased number of services per conception (2.27 vs 1.76).

All of the experimental factors caused differences in the number of services per conception, which allows us to propose them to be included when aiming to improve cow fertility. SPC values deteriorated with the increasing daily milk yield (by 0.6 ), herd size (by $0.37 \mathrm{cow}$ ) and milk somatic cell count (by 0.11 ). The opposite situation occurred for an increase in herd production level and lengthening of the interval between calving and first insemination. Summer was the least favourable period for insemination and winter the most favourable ( $\mathrm{SPC}=2.28$ vs 2.16 ). 
Citation: Siatka K, Sawa A, Czopek SK, Piwczyński D, Bogucki M (2017) Effect of Some Factors on Number of Services per Conception in Dairy Cows. J Vet Sci Technol 8: 465. doi: 10.4172/2157-7579.1000465

\section{References}

1. Piccardi M, Capitaine Funes A, Balzarini M, Bó GA (2013) Some factors affecting the number of days open in Argentinean dairy herds. Theriogenology 79: $760-765$.

2. Borkowska D, Piątek D, Januś E, Mucha J (2012) Fertility of cows in a highyielding herd. Rocz Nauk PTZ 8: 21-29.

3. Ghiasi H, Piwczyński D, Khaldari M, Kolenda M (2015) Application of classification trees in determining the impact of phenotypic factors on conception to first service in Holstein cattle. Anim Prod Sci 56: 1061-1069.

4. Mordak R (2008) The basics of monitoring reproduction in cattle herds. Life of Veterinary 83: 736-741.

5. Bastin C, Vandenplas J, Gengler N (2014) Improving dairy cow fertility using milk based indicator traits. Proceedings 10th World Congress of Genetics Applied to Livestock Production.

6. Januś E, Borkowska D (2013) The effect of selected non-genetic factors on key fertility indicies in high-yielding Montbéliarde cows. Acta Sci Pol Zootech 12: $21-32$

7. Smith RF, Oultram J, Dobson H (2014) Herd monitoring to optimise fertility in the dairy cow: making the most of herd records, metabolic profiling and ultrasonography (research into practice). Animal 8: 185-198.

8. Leroy JLMR, Vanholder T, Van Knegsel ATM, Garcia-Ispierto I, Bols PEJ (2008) Nutrient prioritization in dairy cows early postpartum: mismatch between metabolism and fertility? Reprod Domest Anim 2: 96-103

9. Strucken EM, Bortfeld RH, Tetens G, Thaller G, Brockmann GA (2012) Genetic effects and correlations between production and fertility traits and their dependency on the lactation-stage in Holstein Friesians. BMC Genet 13: 108.

10. Green JC, Meyer JP, Williams AM, Newsom EM, Keisler DH, et al. (2012) Pregnancy development from day 28 to 42 of gestation in postpartum Holstein cows that were either milked (lactating) or not milked (not lactating) after calving. Reproduction 143: 699-711.

11. Stratman TJ, Moore SG, Lamberson WR, Keisler DH, Poock SE, et al (2016) Growth of the conceptus from day 33 to 45 of pregnancy is minimally assiociated with concurrent hormonal or metabolic status in postpartum dairy cows. Anim Reprod Sci 168: 10-18.

12. SAS Institute Inc. (2014) SAS/STAT 9.4 User's Guide. Cary. NC: SAS Institute Inc.

13. Skrzypek R, Antkowiak I, Pytlewski J (2007) Effect of somatic cell counts in milk on cow fertility. Med Wet 63: 1247-1250.

14. Juozaitiene $V$, Juozaitis $A$ (2005) The influence of somatic cell count in milk on reproductive traits and production of Black-and-White cows. Vet Archiv 75 407-414

15. Lavon Y, Ezra E, Leitner G, Wolfenson D (2011) Associataion of conception rate with pattern and level of somatic cell count elevationrelative to time of insemination in dairy cows. J Dairy Sci $94: 4538-4545$.

16. Muller CJC, Potgieter JP, Cloete SWP, Dzama K (2014) Non-genetic factors affecting fertility traits in South African Holstein cows. S Afr J Anim Sci 44: 54-63.

17. Vacek M, Stádník L, Štípková M (2007) Relationships between the incidence of health disorders and the reproduction traits of Holstein cows in the Czech Republic. Czech J Anim Sci 52: 227-235.

18. Ahmadzadeh A, Frago F, Shafii B, Dalton JC, Price WJ, et al. (2009) Effect of clinical mastitis and other diseases on reproductive performances of Holstein cows. Anim Reprod Sci 112: 273-282.
19. Chebel RC, Santos JEP, Reynolds JP, Cerri RLA, Juchem SO, et al. (2004) Factors affecting conception rate after artificial insemination and pregnancy loss in lactating dairy cows. Anim Reprod Sci 84: 239-255.

20. El-Tarabany MS, El-Tarabany AA (2015) Impact of maternal heat stress at insemination on the subsequent reproductive performance of Holstein, Brown Swiss, and their crosses. Theriogenology 84: 1523-1529.

21. Keskın A, Mecıtoğlu G, Bılen E, Güner B, Orman A, et al. (2016) The effect of ovulatory follicle size at the time of insemination on pregnancy rate in lactating dairy cows. Turk J Vet Anim Sci 40: 68-74.

22. Atzori AS, Cannas A (2011) Delayed response to heat stress in dairy cows. Ital J Anim Sci 10: 97.

23. Řehák D, Rajmon R, Kubešová M, Štípkowá $M$, Volek J, et al. (2009) Relationships between milk urea and production and fertility traits in Holstein dairy herds in the Czech Republic. Czech J Anim Sci 54: 193-200.

24. Yusuf M, Nakao T, Yoshida C, Long ST, Gautam G, et al. (2011) Days in milk at first $\mathrm{Al}$ in dairy cows; Its effect on subsequent reproductive performance and some factors influencing it. J Reprod Dev 57: 653-659.

25. Lomander H, Svensson C, Hallén-Sandgren C, Gustafsson H, Frössling J (2013) Associations between decreased fertility and management factors, claw health, and somatic cell count in Swedish dairy cows. J Dairy Sci 96: 6315-6323.

26. Kowalski $Z$ (2010) The impact of feeding on the fertility of dairy cows. Life of Veterinary 85: 830-834

27. Drackley JK, Cardoso FC (2014) Prepartum and postpartum nutritiona management to optimize fertility in high-yielding dairy cows in confined TMR systems. Animal 8: 5-14.

28. Zebeli Q, Ghareeb K, Humer E, Metzler-Zebeli BU, Besenfelder U (2015) Nutrition, rumen health and inflamination in the transition period and their role on overall and fertility in dairy cows. Res Vet Sci 103: 126-136.

29. König S, Chang YM, Borstel UU, Gianola D, Simianer H (2008) Genetic and phenotypic relationships among milk urea nitrogen, fertility, and milk yield in Holstein cows. J Dairy Sci 91: 4372-4382.

30. Skrzypek R, Chraplewski H, Białoń K (2005) Relationship between milk urea concentration and cow fertility. Med Wet 61: 536-539.

31. Sawa A, Bogucki M, Krężel-Czopek S (2011) Effect of some factors on relationships between milk urea levels and cow fertility. Arch Tierz 5: 468-476.

32. Nourozi M, Moussavi AH, Abazari M, Zadeh MR (2010) Milk urea nitrogen and fertility in dairy farms. J Anim Vet Adv 9: 1519-1525.

33. Pinedo PJ, Melendez P, Villagomez-Cortes JA, Risco CA (2009) Effect of high somatic cell counts on reproductive performance of Chilean dairy cattle. J Dairy Sci 92: 1575-1580.

34. Morris MJ, Kaneko K, Uppal SK, Walker SL, Jones DN, et al (2013) Effects of high somatic cell counts in milk on reproductive hormones and oestrus behaviour in dairy cows with special reference to thode with concurren lameness. Anim Reprod Sci 141: 20-25.

35. Gunay A, Gunay U (2008) Effects of clinical mastitis on reproductive performance in Holstein cows. Acta Vet Brno 77: 555-560. 